\title{
Picropodophyllin inhibits the growth of Ewing's sarcoma cells through the insulin-like growth factor-1 receptor/Akt signaling pathway
}

\author{
YONG-TAO WU $^{1}$, BAO-JUN WANG ${ }^{2}$, SHENG-WU MIAO $^{1}$ and JIAN-JUN GAO ${ }^{2}$ \\ ${ }^{1}$ Department of Pediatric Orthopedics, Hong Hui Hospital, Xi'an Jiaotong University College Medicine, \\ Xi'an, Shaanxi 710054; ${ }^{2}$ Department of Orthopedics, Shaanxi Province Yangling Demonstration Zone Hospital, \\ Yangling, Shaanxi 712100, P.R. China
}

Received November 22, 2014; Accepted July 29, 2015

DOI: $10.3892 / \mathrm{mmr} .2015 .4266$

\begin{abstract}
Ewing's sarcoma (ES) is the second most common type of pediatric bone tumor, and is associated with a poor prognosis. Picropodophyllin (PPP), a novel selective inhibitor of insulin-like growth factor-1 receptor (IGF-1R), is able to strongly inhibit various types of cancers. However, the effect of IGF-1R on ES remains unclear. Following treatment with various concentrations of PPP for various times, cell viability was determined using an MTT assay. In addition, cell proliferation and apoptosis was investigated separately by bromodeoxyuridine staining and flow cytometry, respectively. The PPP-associated signaling pathway was also investigated. The results of the present study suggested that PPP inhibited cell proliferation and viability of A673 and SK-ES-1 human Ewing's sarcoma cells in a dose- and time-dependent manner. In addition, cell apoptosis rates were increased following treatment with PPP. Further investigation of the underlying mechanism revealed that PPP inhibited Akt phosphorylation. Fumonisin B1, an Akt-specific activator, reversed the inhibitory effects of PPP on cell growth. Furthermore, the results suggested that PPP decreased the expression levels of IGF-1R, a common activator of Akt signaling. PPP inhibited the growth of human Ewing's sarcoma cells by targeting the IGF-1R/Akt signaling pathway. Therefore, PPP may prove useful in the development of an effective strategy for the treatment of Ewing's sarcoma.
\end{abstract}

Correspondence to: Dr Jian-Jun Gao, Department of Orthopedics, Shaanxi Province Yangling Demonstration Zone Hospital, 8 Houji Street, Yangling, Shaanxi 712100, P.R. China

E-mail: jianjungaojt@163.com

Abbreviations: ES, Ewing's sarcoma; PPP, picropodophyllin; IGF-IR, insulin-like growth factor I receptor; FB1, fumonisin B1

Key words: picropodophyllin, proliferation, Ewing's sarcoma, apoptosis, insulin-like growth factor-1 receptor/Akt signaling

\section{Introduction}

Ewing's sarcoma (ES) is the second most common type of primary bone and soft malignant tumor, often occurs in children and adolescents, and is characterized by a pathognomonic chromosomal translocation known as $\mathrm{t}(11 ; 22)$ ( $\mathrm{q} 24 ; \mathrm{q} 12)$ or $\mathrm{t}(21 ; 22)$ (q22;q12) $(1,2)$. Despite rapid advances in modern biomedicinal therapy, the 5 -year survival rate of patients with ES has only reached $50-60 \%(3,4)$. Numerous studies have focused on investigating the underlying mechanism of ES, as well as therapeutic targets for patients with ES; however, the process of ES carcinogenesis remains largely unknown (5-9). Therefore, developing an effective therapeutic strategy for the treatment of ES is critical for young patients.

Insulin-like growth factor 1 receptor (IGF-1R) represents an important therapeutic target in the pathogenesis of ES cells, and is regarded to be an effective biological therapy for ES (10-12). A previous study reported that mutations in IGF-1R may induce apoptosis and inhibit tumorigenesis, as well as enhance chemosensitivity in ES cells (13). Previous studies involving the inhibition of IGF-1R to regulate cell proliferation and apoptosis were also conducted $(14,15)$. Increasing evidence suggests that the IGF-1R inhibitor NVP-AEW541 may possess the ability to enhance cell apoptosis, inhibit proliferation or arrest the cell cycle in ES $(16,17)$. Therefore, identifying more effective inhibitors of IGF-1R may prove to be advantageous in the prevention of ES.

Picropodophyllin (PPP), an epimer of podophyllotoxin, may be a novel selective inhibitor of IGF-1R. PPP strongly inhibits cell growth in various types of cancer, including lymphoma, asopharyngeal carcinoma and colorectal carcinoma (18-21). Although PPP induces apoptosis in cultured IGF-1R-positive tumor cells, the mechanism underlying these effects remains to be elucidated (22). In addition, its effect on ES and the underlying mechanism also remain to be clarified. In the present study, the effects of PPP on the proliferation and apoptosis of ES cell lines was investigated, along with the associated signaling pathway.

\section{Materials and methods}

Cells and culture. A673 and SK-ES-1 human ES cell lines were obtained from the American Type Culture Collection 
(Manassas, VA, USA). The A673 cells $\left(5 \times 10^{5}\right)$ were maintained in RPMI-1640 medium (Gibco Life Technologies, Carlsbad, CA, USA) supplemented with $10 \%$ fetal bovine serum (FBS; Invitrogen Life Technologies, Carlsbad, CA, USA), streptomycin $(100 \mathrm{mg} / \mathrm{ml}$; Shanghai Sangon Biological Engineering Technology \& Services Co., Ltd., Shanghai, China), and penicillin (100 U/ml; Shanghai Sangon Biological Engineering Technology \& Services Co., Ltd.) in a $5 \%$ (v/v) $\mathrm{CO}_{2}$ incubator at $37^{\circ} \mathrm{C}$. The SK-ES-1 cells were cultured in Dulbecco's modified Eagle's medium (DMEM; Invitrogen Life Technologies) supplemented with $15 \%$ FBS. The cells were also incubated in a humidified atmosphere containing $5 \%(\mathrm{v} / \mathrm{v}) \mathrm{CO}_{2}$ at $37^{\circ} \mathrm{C}$.

Cell viability assay. An MTT assay was used to determine the effects of PPP or fumonisin B1 (FB1) on the viability of the ES cell lines. Briefly, the cells were seeded in 96-well plates $\left(3 \times 10^{3}\right.$ cells $\left./ 200 \mu \mathrm{l}\right)$ for $24 \mathrm{~h}$. The cells were treated with various concentrations $(0.05,0.1,0.2,0.4$ and $0.8 \mu \mathrm{M})$ of PPP (cat. no. UNO-000037; 99\% pure; UNO, Zhongshan, China) or $50 \mu \mathrm{M}$ FB1 (Santa Cruz Biotechnology, Inc., Dallas, TX, USA) for 48 h. MTT solution (Sigma-Aldrich, St. Louis, MO, USA) at a final concentration of $0.5 \mathrm{mg} / \mathrm{ml}$ was subsequently added and the samples were incubated for a further $4 \mathrm{~h}$ at $37^{\circ} \mathrm{C}$. The medium (RMPI-1640 or DMEM) was then discarded, and $200 \mu 1$ dimethyl sulfoxide (Gibco Life Technologies) was added to dissolve the formazan dye crystals for $15 \mathrm{~min}$. Absorbance was finally measured at $570 \mathrm{~nm}$ using a microplate reader (Molecular Devices, LLC, Sunny Vale, CA, USA) with a reference wavelength of $630 \mathrm{~nm}$. The results were expressed as a percentage of the MTT reduction, and assumed that the absorbance of the control cells was $100 \%$. Each experiment was performed in triplicate.

Cell proliferation analysis. A bromodeoxyuridine (BrdU) Cell Staining kit (Invitrogen Life Technologies) was used to investigate the effects of PPP on ES cell proliferation, according to the manufacturer's instructions. Briefly, the cells were seeded in 96 -well plates $\left(5 \times 10^{3}\right.$ cells/well) for $24 \mathrm{~h}$, and exposed to various concentrations of PPP for a further $48 \mathrm{~h}$. The cells were then fixed with $10 \mu \mathrm{l} \mathrm{BrdU}$ for $5 \mathrm{~h}$, and the medium (RMPI-1640 or DMEM) was discarded prior to the addition of $100 \mu \mathrm{l} /$ well fixing/denaturing solution (Beyotime Institute of Biotechnology, Nantong, China), incubated at room temperature for $15 \mathrm{~min}$. The solution was then removed and $100 \mu \mathrm{l} /$ well prepared detection antibody solution (mouse anti-human BrdU monoclonal antibody) was added and incubated for $1 \mathrm{~h}$ at room temperature. The plates were then washed three times with phosphate-buffered saline (PBS), followed by the addition of $100 \mu \mathrm{l} /$ well horseradish peroxidase (HRP)-conjugated secondary antibody solution, incubated for $30 \mathrm{~min}$ at room temperature. The plates were further washed three times with washing buffer, and $100 \mu \mathrm{l}$ 3,3',5,5'-tetramethylbenzidine substrate was added, and incubated for $30 \mathrm{~min}$ at room temperature. The quantity of BrdU incorporated into the cells was determined at $450 \mathrm{~nm}$ using a microplate reader (Bio-Rad Laboratories, Inc., Hercules, CA, USA).

Apoptosis analysis. The cell lines cultured in RPMI-1640 were seeded in 96 -well plates $\left(2 \times 10^{4}\right.$ cells/well $)$, treated with
PPP or FB1 for $24 \mathrm{~h}$, and harvested with trypsin (Gibco Life Technologies). Following two washes with PBS on ice, the cells were incubated with fluorescein isothiocyanate-conjugated Annexin V (Sigma-Aldrich) in binding buffer $(50 \mathrm{mM}$ HEPES, $700 \mathrm{mM} \mathrm{NaCl}, 12.5 \mathrm{mM} \mathrm{CaCl}_{2}$, pH 7.4) for $20 \mathrm{~min}$ at $37^{\circ} \mathrm{C}$ in the dark. The cells were then washed with PBS, and incubated with $10 \mathrm{ml}$ phosphatidylinositol (PI) solution (1 mg/ml; Sigma-Aldrich) for $20 \mathrm{~min}$ at room temperature in the dark. The cells were then analyzed at $488 \mathrm{~nm}$ and $633 \mathrm{~nm}$ using a FACScan Flow Cytometer (BD Biosciences, Franklin Lakes, NJ, USA) to determine the relative apoptosis levels.

Western blot analysis. For western blot analysis, the cells were lysed with $2 \mathrm{X}$ lysis buffer containing $250 \mathrm{mM}$ Tris- $\mathrm{HCl}$ (pH 6.5), 2\% SDS, 4\% $\beta$-mercaptoethanol, $0.02 \%$ bromphenol blue and $10 \%$ glycerol. Protein concentration was determined using a Bicinchoninic Acid Protein Assay kit (Bio-Rad Laboratories, Inc.) and equal quantities of protein were analyzed by SDS-PAGE (20 mg/lane) on a $5 \%$ stacking gel and a $10 \%$ separating gel (Beyotime Institute of Biotechnology), prior to being transferred onto polyvinylidene difluoride membranes (EMD Millipore, Billerica, MA, USA) at $10 \mathrm{~V}$ for $30 \mathrm{~min}$. The membranes were blocked for $2 \mathrm{~h}$ with $5 \%$ non-fat dry milk in Tris-buffered saline containing $0.1 \%$ Tween-20 (Beyotime Institute of Biotechnology) (TBST), and incubated at $4^{\circ} \mathrm{C}$ overnight with the following primary antibodies: Rabbit anti-human Akt (cat. no. 9272; Cell Signaling Technology, Inc., Danvers, MA, USA; 1:1,000), rabbit anti-human phosphorylated (p)-Akt (cat. no. SAB4301497; Sigma-Aldrich; 1:800), rabbit anti-human p-IGF-1R (cat. no. I2033; Sigma-Aldrich; 1:500), rabbit anti-human IGF-1R (cat. no. 3027; Cell Signaling Technology, Inc.; 1:800) and mouse anti-human $\beta$-actin (cat. no. 3700; Cell Signaling Technology, Inc.; 1:1,000). Following washing with TBST, the membranes were incubated with HRP-conjugated goat anti-rabbit IgG (cat. no. A0545; Sigma-Aldrich; 1:80,000) or HRP-conjugated horse anti-mouse IgG (cat. no. 7076; Cell Signaling Technology, Inc.; 1:20,000) secondary antibodies targeting rabbit or mouse in TBST for $45 \mathrm{~min}$ at room temperature. Following three washes with TBST, the proteins were developed using an Enhanced Chemiluminescence kit (GE Healthcare Life Sciences, Chalfont, UK). Detection was performed using an Enhanced Chemiluminescence system (EMD Millipore).

Statistical analysis. The results are expressed as the mean \pm standard deviation of at least three independent experiments. Statistical analysis was conducted using SPSS 16.0 (SPSS, Inc., Chicago, IL, USA). The statistical significance of the differences between the control and drug-treated groups were evaluated using an unpaired Student's t-test. $\mathrm{P}<0.05$ was considered to indicated a statistically significant result.

\section{Results}

PPP inhibits cell viability in a dose- and time-dependent manner. Cell viability evaluation is one of the most important steps in the quality control process for therapeutic drug use (23). To investigate the effects of PPP on ES, an MTT assay was first used to assess the influence of PPP on the cell growth of 

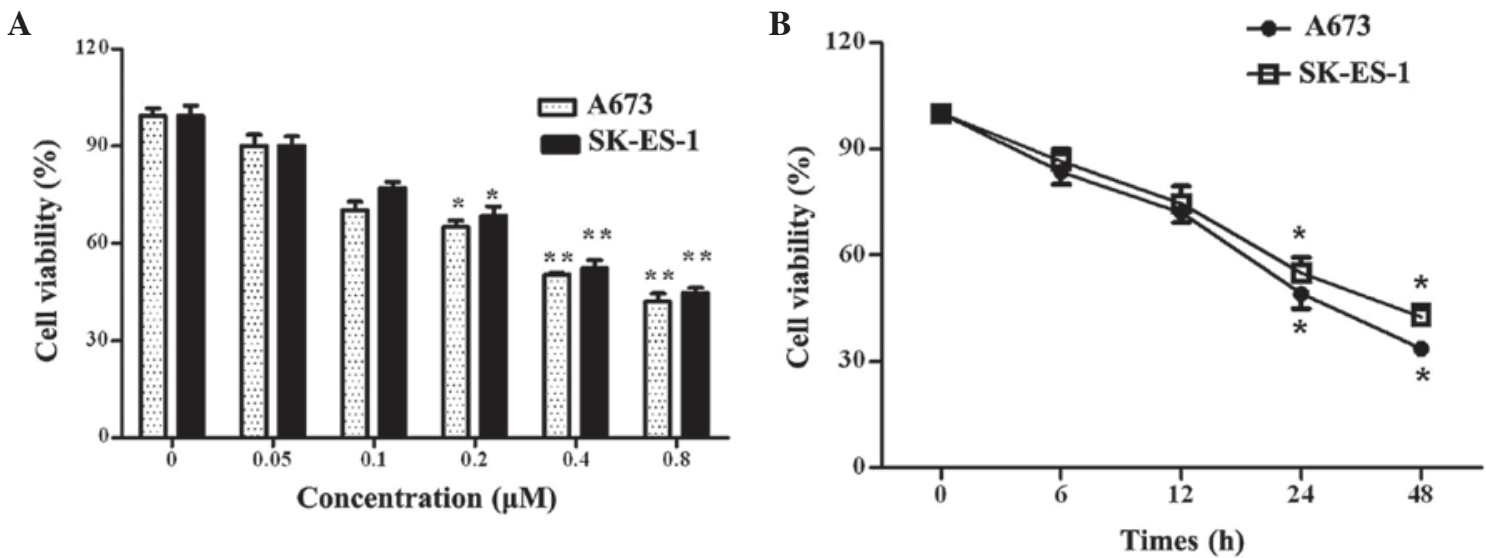

Figure 1. Effects of PPP on Ewing's sarcoma cell viability in vitro. (A) A673 and SK-ES-1 cell lines were treated with various concentrations of PPP $(0,0.05,0.1,0.2,0.4$ and $0.8 \mu \mathrm{M})$. A total of $48 \mathrm{~h}$ later, an MTT assay was performed to analyze cell viability. The error bars represent the mean \pm standard deviation. (B) Following treatment with $0.4 \mu \mathrm{M}$ PPP for $6,12,24$ or $48 \mathrm{~h}$, cell viability was detected using an MTT assay. ${ }^{*} \mathrm{P}<0.05$ and ${ }^{* *} \mathrm{P}<0.01$, vs. the control group. PPP, picropodophyllin.

A

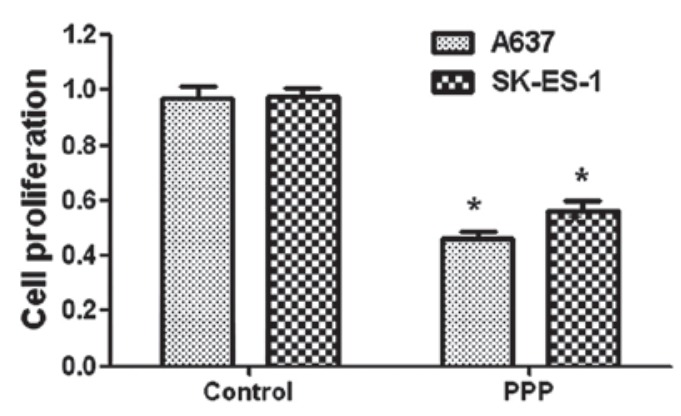

C

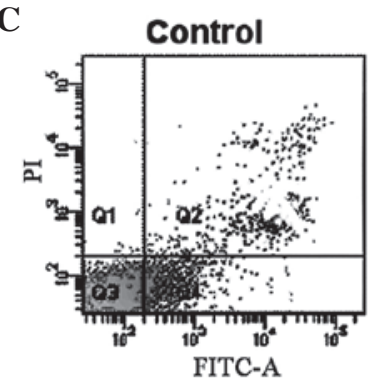

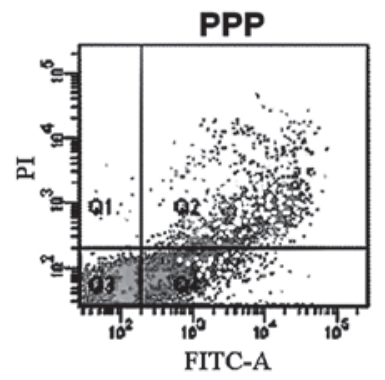

A673
B
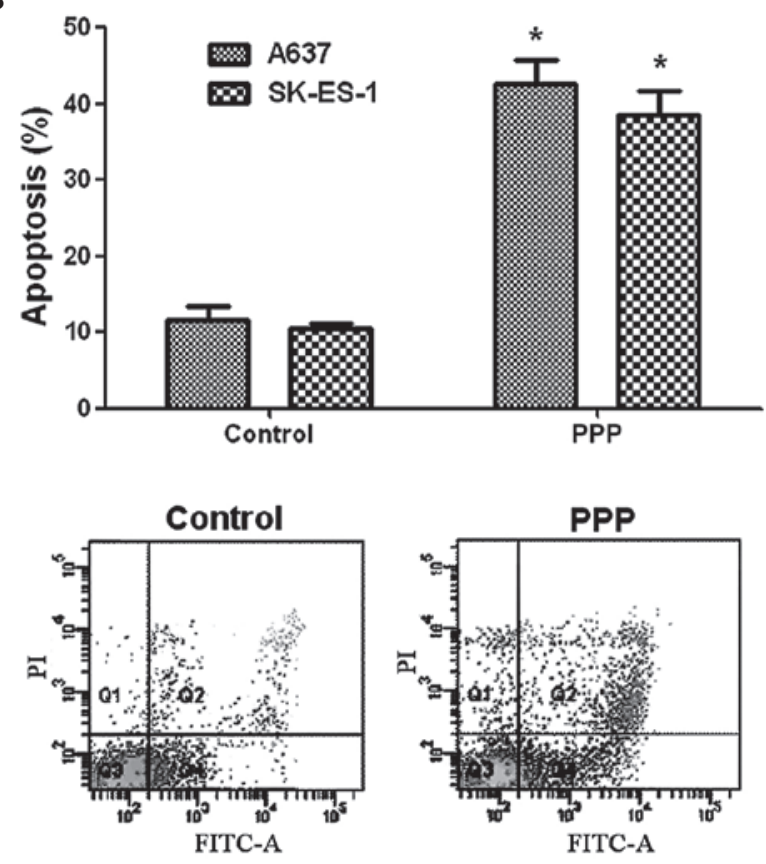

SK-ES-1

Figure 2. Effects of PPP on cell proliferation and apoptosis. (A) Cell proliferation was determined using a bromodeoxyuridine cell staining kit, and was inhibited by PPP. (B) Cell apoptosis was determined by Annexin V/PI staining, and was induced by PPP. (C) The distribution of apoptotic cells induced by PPP. The data are presented as the mean \pm standard deviation. ${ }^{*} \mathrm{P}<0.05$, vs. the control group. PPP, picropodophyllin; PI, propidium iodide.

the A673 and SK-ES-1 ES cell lines. As shown in Fig. 1A, PPP inhibited A673 and SK-ES-1 cell viability in a dose-dependent manner, and the half maximal inhibitory concentration $\left(\mathrm{IC}_{50}\right)$ values for the A673 and SK-ES-1 cell lines were 0.42 and $0.48 \mu \mathrm{M}$, respectively. Further analysis determined that PPP exhibited time-dependent inhibitory effects on A673 and SK-ES-1 cell viability. As shown in Fig. 1B, the percentage of A673 and SK-ES-1 cell viability declined significantly at $24 \mathrm{~h}$, and the rates of cell viability were 49 and $52 \%$, respectively, as compared with the control $(\mathrm{P}<0.05)$. These results suggest that PPP inhibits cell viability in a dose- and time-dependent manner.
Effects of PPP on cell proliferation. To evaluate the effects of PPP on ES cell proliferation, a BrdU cell staining kit was used. As shown in Fig. 2A, PPP was able to inhibit $>50 \%$ of A673 cells at an value $\mathrm{IC}_{50}$ of $0.42 \mu \mathrm{M}$. Although the effect of PPP on the SK-ES-1 cells was more marked than that on the A673 cells, cell viability still decreased by $44 \%$ in the A673 cells. These results suggest that PPP is able to inhibit ES cell survival.

PPP treatment induces ES cell apoptosis. To further evaluate the effect of PPP on cell apoptosis, Annexin V/PI double staining was performed on the A673 and SK-ES-1 cells. The 
A

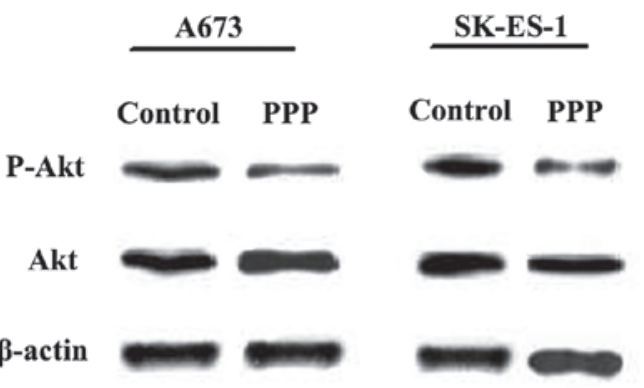

C

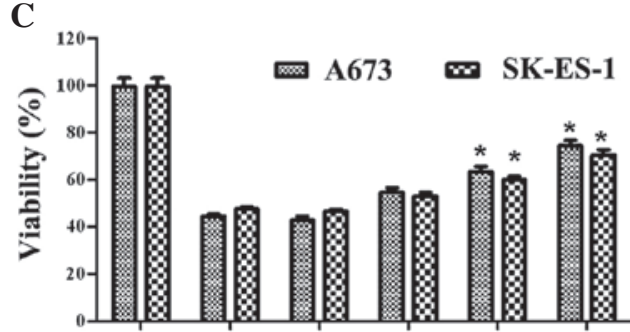

PPP

DMSO

$\mathrm{FB} 1(\mu \mathrm{g} / \mathrm{ml})$ -
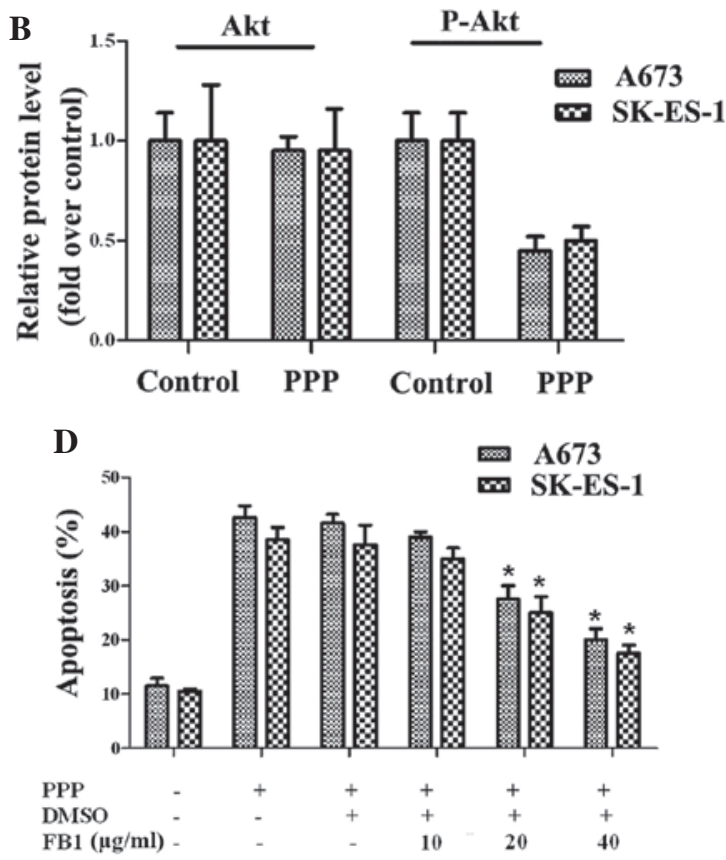

Figure 3. PPP affects Akt phosphorylation in A673 and SK-ES-1 cell lines. (A) The effects of PPP on Akt phosphorylation, as determined by western blotting. (B) The quantification of Akt and p-Akt protein expression levels in A673 and SK-ES-1 cell lines. (C) The effects of FB1 on cell viability, as determined by an MTT assay. (D) The effects of FB1 on PPP-induced apoptosis. ${ }^{* *} \mathrm{P}<0.01$, vs. the control and ${ }^{*} \mathrm{P}<0.05$, vs. the PPP-treated group. PPP, picropodophyllin; p, phosphorylated; FB1, fumonisin B1; DMSO, dimethyl sulfoxide.

$\mathbf{A}$

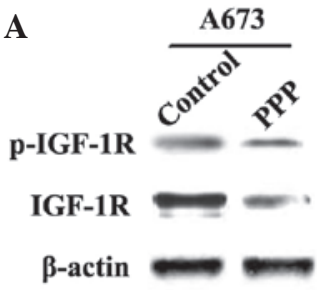

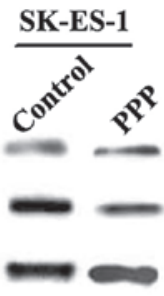

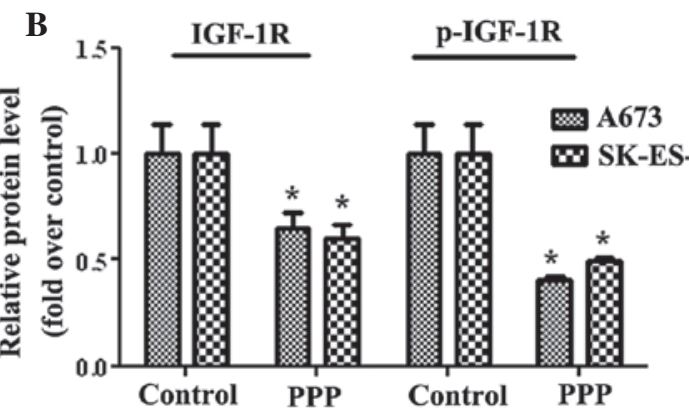

Figure 4. PPP decreased the expression levels of IGF-1R and p-IGF-1R in A673 and SK-ES-1 cell lines. (A) Following treatment with PPP, the expression levels of IGF-1R and p-IGF-1R were measured by western blotting. (B) The relative protein expression levels of IGF-1R and p-IGF-1R in the A673 and SK-ES-1 cell lines. " $\mathrm{P}<0.01$, vs. the control. PPP, picropodophyllin; p, phosphorylated; IGF-1R, insulin-like growth factor 1 receptor.

SK-ES-1 cell apoptotic rates were significantly increased from 10.1 (control) to 38.5\% (PPP-treated) (Fig. 2B). The apoptotic rates induced by PPP are shown in Fig. 2C. The apoptotic rates in the A673 cells were significantly increased from $11.2 \%$ (control) to $40.8 \%$ (PPP-treated) following treatment with $0.42 \mu \mathrm{M}$ PPP. These data demonstrated the effect of PPP on cell apoptosis in the A673 and SK-ES-1 cells.

PPP blocks ES cell growth through Akt signaling. The Akt signaling pathway has an important role in cell progression, including proliferation and apoptosis. The activation of Akt improves the survival of ES cell lines (24). To explore the mechanism underlying the effects of PPP on cell growth, the effects of PPP on Akt expression were detected in the A673 and SK-ES-1 cell lines. As shown in Fig. 3A and B, the total Akt levels remained unchanged, whereas the phosphorylation levels of Akt markedly decreased in the two cell lines. Therefore, PPP may inhibit ES cell growth via Akt signaling. To further verify this hypothesis, FB1, a specific activator of Akt, was used for subsequent study. Following pre-treatment with FB1, the viability of the A673 and SK-ES-1 cells was significantly increased. The viability of the A673 cells increased from 42.8 to $63.5 \%$, following the addition of $20 \mu \mathrm{g} / \mathrm{ml} \mathrm{FB1}$. In addition, PPP-inhibited cell viability in the SK-ES-1 cells increased from 44 to 53,60 and $70.5 \%$, respectively, following treatment with various doses of FB1 (Fig. 3C). Conversely, PPP-induced cell apoptosis was decreased from 42.55 to $20 \%(40 \mu \mathrm{g} / \mathrm{ml}$ FB1-treated groups) in the A673 cells, following treatment with FB1. Furthermore, apoptotic rates in the SK-ES-1 cells also decreased from 38.55 (PPP-treated) to $17.5 \%(40 \mu \mathrm{g} / \mathrm{ml}$ FB1-treated; Fig. 3D). These results suggest that PPP markedly inhibits A673 and SK-ES-1 cell growth by blocking Akt signaling.

Effects of PPP on IGF-1R activation. IGF-1R is overexpressed in various tumors, including breast tumors, 
prostate tumors and myeloma (25). In addition, IGF-1R has an important role in the prevention of apoptosis by inducing the Akt signaling transduction cascade (26). To further investigate the PPP-regulated Akt signaling pathway in ES, the expression levels of IGF-1R were analyzed. Total IGF-1R expression levels in the A673 cells decreased by $\sim 35 \%$ compared with untreated cells, whereas SK-ES-1 cells exhibited a $40 \%$ decrease in IGF-1R expression (Fig. 4). Similarly, the phosphorylation levels of IGF-1R decreased by $>50 \%$, as compared with those of the control cells in the two cell lines. The A673 cells exhibited a 59\% decrease in the phosphorylation levels of IGF-1R, and the SK-ES-1 cells a $50.5 \%$ decrease, as compared with the control group. As an inhibitor of IGF-1R, PPP significantly reduced the expression and phosphorylation levels of IGF-1R. These results suggest that PPP regulates ES cell growth via the IGF-1R/Akt signaling pathway.

\section{Discussion}

ES is a relatively rare type of malignancy predominantly occurring between the ages of four and $25(27,28)$. The aim of current research is to acquire a greater understanding of the biological pathogenesis of ES, and to identify an effective drug for the treatment of ES (29). Previous studies demonstrated that PPP inhibits numerous types of cancers, including osteosarcoma and human multiple myeloma $(30,31)$; however, no research has been performed to date on ES. To the best of our knowledge, the present study is the first to investigate the function of PPP in ES. The results of the present study demonstrated that PPP induces proliferation inhibition and apoptotic enhancement in human ES cell lines. Therefore, PPP may be effective in the inhibition of ES, and merits further investigation.

Numerous molecular studies have demonstrated that the Akt signal transduction cascade usually participates in ES cell progression, cell apoptosis, cell proliferation and drug susceptibility (32-34). As an IFG-1R inhibitor, PPP was found to have Akt inhibitory effects in neuroblastoma cell lines (35). Furthermore, the efficacy of PPP against multiple myeloma has also been demonstrated (31). To further investigate the mechanism underlying the cell growth inhibitory effects of PPP, the present study investigated the Akt signaling pathway in ES. The results indicated that PPP induced downregulation of p-Akt expression by $~ 50 \%$. The inhibitory effect of PPP on p-Akt was recovered following treatment with an Akt-specific activator, FB1. These results demonstrated that PPP was indeed able to inhibit human ES survival by blocking the Akt signaling pathway.

Recently, IGF signaling has become a potential target for novel anticancer agents $(36,37)$. IGF-1R is an activator of the Akt signaling pathway. The IGF-1R-mediated Akt signaling pathway exhibited anticancer effects in various types of cancer $(38,39)$. Baumgarten et al (40) suggested that IGF-1R signaling may be required for Akt activation. Previous studies have also demonstrated the association between IFG-1R and Akt $(41,42)$. In the present study, PPP appeared to block IGF-1R phosphorylation. Consequently, it was hypothesized that PPP may inhibit ES growth by inhibiting the IGF-1R-Akt signaling pathway.
In conclusion, the present study demonstrated the effectiveness of PPP in human ES. The inhibition of cell survival, as well as the effective induction of apoptosis, led to further investigation of the underlying mechanism. The IGF-1R/Akt signaling pathway was shown to involve the PPP-induced survival in ES cells. Therefore, the application of PPP may provide a novel therapeutic strategy for the treatment of ES.

\section{References}

1. Iwamoto Y: Diagnosis and treatment of Ewing's sarcoma. Jpn J Clin Oncol 37: 79-89, 2007

2. Delattre O,Zucman J, Melot T, Garau XS, Zucker JM, Lenoir GM, Ambros PF, Sheer D, Turc-Carel C and Triche TJ: The Ewing family of tumors-a subgroup of small-round-cell tumors defined by specific chimeric transcripts. N Engl J Med 331: 294-299, 1994.

3. de Alava E and Gerald WL: Molecular biology of the Ewing's sarcoma/primitive neuroectodermal tumor family. J Clin Oncol 18: 204-213, 2000

4. Burgert EO Jr, Nesbit ME, Garnsey LA, Gehan EA, Herrmann J, Vietti TJ, Cangir A, Tefft M, Evans R and Thomas P: Multimodal therapy for the management of nonpelvic, localized Ewing's sarcoma of bone: Intergroup study IESS-II. J Clin Oncol 8: 1514-1524, 1990.

5. Kontny U: Regulation of apoptosis and proliferation in Ewing's sarcoma-opportunities for targeted therapy. Hematol Oncol 24: 14-21, 2006.

6. Tanaka K, Iwakuma T, Harimaya K, Sato H and Iwamoto Y: EWS-Fli1 antisense oligodeoxynucleotide inhibits proliferation of human Ewing's sarcoma and primitive neuroectodermal tumor cells. J Clin Invest 99: 239-247, 1997.

7. Kinsey M, Smith R and Lessnick SL: NR0B1 is required for the oncogenic phenotype mediated by EWS/FL1 in Ewing's sarcoma. Mol Cancer Res 4: 851-859, 2006.

8. Kauer M, Ban J, Kofler R, Walker B, Davis S, Meltzer P and Kovar H: A molecular function map of Ewing's sarcoma. PLoS One 4: e5415, 2009.

9. Rocchi A, Manara MC, Sciandra M, Zambelli D, Nardi F, Nicoletti G, Garofalo C, Meschini S, Astolfi A, Colombo MP, et al: CD99 inhibits neural differentiation of human Ewing sarcoma cells and thereby contributes to oncogenesis. J Clin Invest 120: 668-680, 2010.

10. Scotlandi K, Maini C, Manara MC, Benini S, Serra M, Cerisano V, Strammiello R, Baldini N, Lollini PL, Nanni P, et al: Effectiveness of insulin-like growth factor I receptor antisense strategy against Ewing's sarcoma cells. Cancer Gene Ther 9: 296-307, 2002.

11. Kang HG, Jenabi JM, Liu XF, Reynolds CP, Triche TJ and Sorensen PH: Inhibition of the insulin-like growth factor I receptor by epigallocatechin gallate blocks proliferation and induces the death of Ewing tumor cells. Mol Cancer Ther 9: 1396-1407, 2010.

12. Prieur A, Tirode F, Cohen P and Delattre O: EWS/FLI-1 silencing and gene profiling of Ewing cells reveal downstream oncogenic pathways and a crucial role for repression of insulin-like growth factor binding protein 3. Mol Cell Biol 24: 7275-7283, 2004.

13. Scotlandi K, Avnet S, Benini S, Manara MC, Serra M, Cerisano V, Perdichizzi S, Lollini PL, De Giovanni C, Landuzzi L and Picci P: Expression of an IGF-I receptor dominant negative mutant induces apoptosis, inhibits tumorigenesis and enhances chemosensitivity in Ewing's sarcoma cells. Int J Cancer 101: 11-16, 2002.

14. Benini S, Manara MC, Baldini N, Cerisano V, Massimo Serra, Mercuri M, Lollini PL, Nanni P, Picci P and Scotlandi K: Inhibition of insulin-like growth factor I receptor increases the antitumor activity of doxorubicin and vincristine against Ewing's sarcoma cells. Clin Cancer Res 7: 1790-1797, 2001.

15. Scotlandi K, Benini S, Sarti M, Serra M, Lollini PL, Maurici D, Picci P, Manara MC and Baldini N: Insulin-like growth factor I receptor-mediated circuit in Ewing's sarcoma/peripheral neuroectodermal tumor: A possible therapeutic target. Cancer Res 56: 4570-4574, 1996.

16. Scotlandi K, Manara MC, Nicoletti G, Lollini PL, Lukas S, Benini S, Croci S, Perdichizzi S, Zambelli D, Serra M, et al: Antitumor activity of the insulin-like growth factor-I receptor kinase inhibitor NVP-AEW541 in musculoskeletal tumors. Cancer Res 65: 3868-3876, 2005 
17. Manara MC, Landuzzi L, Nanni P, Nicoletti G, Zambelli D, Lollini PL, Nanni C, Hofmann F, García-Echeverría C, Picci P and Scotlandi K: Preclinical in vivo study of new insulin-like growth factor-I receptor-specific inhibitor in Ewing's sarcoma. Clin Cancer Res 13: 1322-1330, 2007.

18. Huang Z, Fang Z, Zhen H, Zhou L, Amin HM and Shi P: Inhibition of type I insulin-like growth factor receptor tyrosine kinase by picropodophyllin induces apoptosis and cell cycle arrest in T lymphoblastic leukemia/lymphoma. Leuk Lymphoma 55: 1876-1883, 2014

19. Yin SC, Guo W and Tao ZZ: Picropodophyllin inhibits tumor growth of human nasopharyngeal carcinoma in a mouse model. Biochem Biophys Res Commun 439: 1-5, 2013.

20. Wang Q, Wei F, Lv G, Li C, Liu T, Hadjipanayis CG, Zhang G, Hao C and Bellail AC: The association of TP53 mutations with the resistance of colorectal carcinoma to the insulin-like growth factor-1 receptor inhibitor picropodophyllin. BMC Cancer 13: $521,2013$.

21. Lu X, Wang L, Mei J, Wang X, Zhu X, Zhang Q and Lv J: Picropodophyllin inhibits epithelial ovarian cancer cells in vitro and in vivo. Biochem Biophys Res Commun 435: 385-390, 2013.

22. Hixon ML, Paccagnella L, Millham R, Perez-Olle R and Gualberto A: Development of inhibitors of the IGF-1R/PI3K/Akt/mTOR pathway. Rev Recent Clin Trials 5: 189-208, 2010.

23. Martin-Piedra MA, Garzon I, Oliveira AC Alfonso-Rodriguez CA, Carriel V, Scionti G and Alaminos M: Cell viability and proliferation capability of long-term human dental pulp stem cell cultures. Cytotherapy 16: 266-277, 2014.

24. Li J, You T and Jing J: MiR-125b inhibits cell biological progression of Ewing's sarcoma by suppressing the PI3K/Akt signalling pathway. Cell Prolif 47: 152-160, 2014.

25. Bertrand FE, Steelman LS, Chappell WH, Abrams SL, Shelton JG, White ER, Ludwig DL and McCubrey JA: Synergy between an IGF-1R antibody and Raf//MEK//ERK and PI3K//Akt//mTOR pathway inhibitors in suppressing IGF-1R-mediated growth in hematopoietic cells. Leukemia 20: 1254-1260, 2006.

26. Shelton JG, Steelman LS, White ER and McCubrey JA: Synergy between PI3K/Akt and Raf/MEK/ERK pathways in IGF-1R mediated cell cycle progression and prevention of apoptosis in hematopoietic cells. Cell Cycle 3: 372-379, 2004

27. Yang Y, Li H, Zhang F, Shi H, Zhen T, Dai S, Kang L, Liang Y, Wang $J$ and Han A: Clinical and biological significance of hepatoma-derived growth factor in Ewing's sarcoma. J Pathol 231: 323-334, 2013.

28. Gorelik N, Dickson BC, Wunder JS and Bleakney R: Ewing's sarcoma of the patella. Skeletal Radiol 42: 729-733, 2013.

29. Sankar S and Lessnick SL: Promiscuous partnerships in Ewing's sarcoma. Cancer Genet 204: 351-365, 2011.

30. Duan Z, Choy E, Harmon D, Yang C, Ryu K, Schwab J, Mankin $\mathrm{H}$ and Hornicek FJ: Insulin-like growth factor-I receptor tyrosine kinase inhibitor cyclolignan picropodophyllin inhibits proliferation and induces apoptosis in multidrug resistant osteosarcoma cell lines. Mol Cancer Ther 8: 2122-2130, 2009.
31. Menu E, Jernberg-Wiklund H, De Raeve H, De Leenheer E, Coulton L, Gallagher O, Van Valckenborgh E, Larsson O, Axelson M, Nilsson K, et al: Targeting the IGF-1R using picropodophyllin in the therapeutical 5T2MM mouse model of multiple myeloma: beneficial effects on tumor growth, angiogenesis, bone disease and survival. Int J Cancer 121: 1857-1861, 2007.

32. Krishnan K, Bruce B, Hewitt S, Thomas D, Khanna C and Helman LJ: Ezrin mediates growth and survival in Ewing's sarcoma through the AKT/mTOR, but not the MAPK, signaling pathway. Clin Exp Metastasis 23: 227-236, 2006.

33. Kilic-Eren M, Boylu T and Tabor V: Targeting PI3K/Akt represses Hypoxia inducible factor-1alpha activation and sensitizes Rhabdomyosarcoma and Ewing's sarcoma cells for apoptosis. Cancer Cell Int 13: 36, 2013.

34. Li J, You T and Jing J: MiR-125b inhibits cell biological progression of Ewing's sarcoma by suppressing the PI3K/Akt signalling pathway. Cell Prolif 47: 152-160, 2014.

35. Qi L, Toyoda H, Shankar V, Sakurai N, Amano K, Kihira K, Iwasa T, Deguchi T, Hori H, Azuma E, et al: Heterogeneity of neuroblastoma cell lines in insulin-like growth factor 1 receptor/Akt pathway-mediated cell proliferative responses. Cancer Sci 104: 1162-1171, 2013.

36. Bähr C and Groner B: The insulin like growth factor-1 receptor (IGF-1 R) as a drug target: Novel approaches to cancer therapy. Growth Horm IGF Res 14: 287-295, 2004.

37. Bianco R, Melisi D, Ciardello F and Tortora G: Key cancer cell signal transduction pathways as therapeutic targets. Eur J Cancer 42: 290-294, 2006.

38. Fabian J,Lodrini M, Oehme I, Schier MC, Thole TM, Hielscher T, Kopp-Schneider A, Opitz L, Capper D, von Deimling A, et al: GRHL1 acts as tumor suppressor in neuroblastoma and is negatively regulated by MYCN and HDAC3. Cancer Res 74: 2604-2616, 2014

39. Estañ MC, Calviño E, de Blas E, Boyano-Adanez Mdel C, Mena ML, Gómez-Gómez M, Rial E and Aller P: 2-Deoxy-D-glucose cooperates with arsenic trioxide to induce apoptosis in leukemia cells: Involvement of IGF-1R-regulated Akt/mTOR, MEK/ERK and LKB-1/AMPK signaling pathways. Biochem Pharmacol 84: 1604-1616, 2012.

40. Baumgarten SC, Convissar SM, Fierro MA, Winston NJ, Scoccia B and Stocco C: IGF-1R signaling is necessary for FSH-induced activation of $\mathrm{AKT}$ and differentiation of human cumulus granulosa cells. J Clin Endocrinol Metab 99: 2995-3004, 2014.

41. Chen C, Xu Y and Song Y: IGF-1 gene-modified muscle-derived stem cells are resistant to oxidative stress via enhanced activation of IGF-1R/PI3K/AKT signaling and secretion of VEGF. Mol Cell Biochem 386: 167-175, 2014.

42. Jiang YY, Huang $\mathrm{H}$, Wang $\mathrm{HJ}$, Wu D, Yang $\mathrm{R}$, Tashiro $\mathrm{S}$, Onodera $S$ and Ikejima $\mathrm{T}$ : Interruption of mitochondrial complex IV activity and cytochrome c expression activated $\mathrm{O}_{2} \cdot$-mediated cell survival in silibinin-treated human melanoma A375-S2 cells via IGF-1R-PI3K-Akt and IGF-1R-PLC gamma-PKC pathways. Eur J Pharmacol 668: 78-87, 2011. 